\title{
COVID-19 and China's attempts to build a health silk road to Myanmar
}

Edition 8, 2021

Dr Nyi Nyi Kyaw

DOI: 10.37839/MAR2652-550X8.3

The Chinese Embassy in Myanmar posted, in Burmese on its Facebook page, on 2 October 2021: 


\section{MELBOURNE ASIA REVIEW}

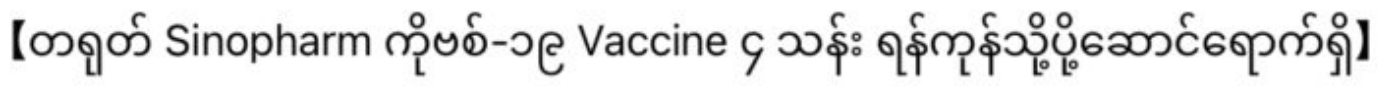

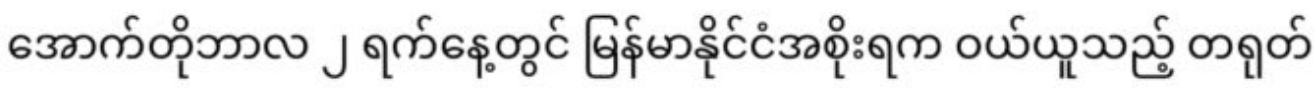

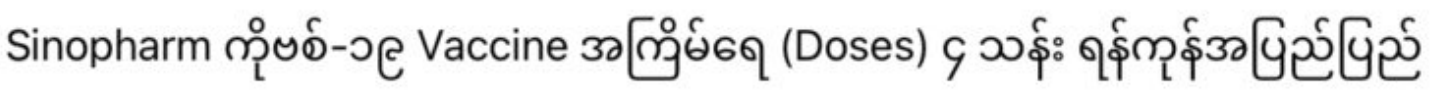
ఖำ

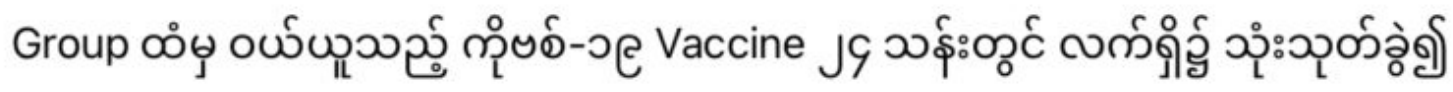

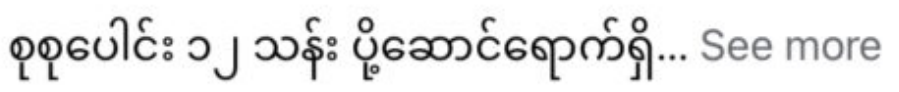

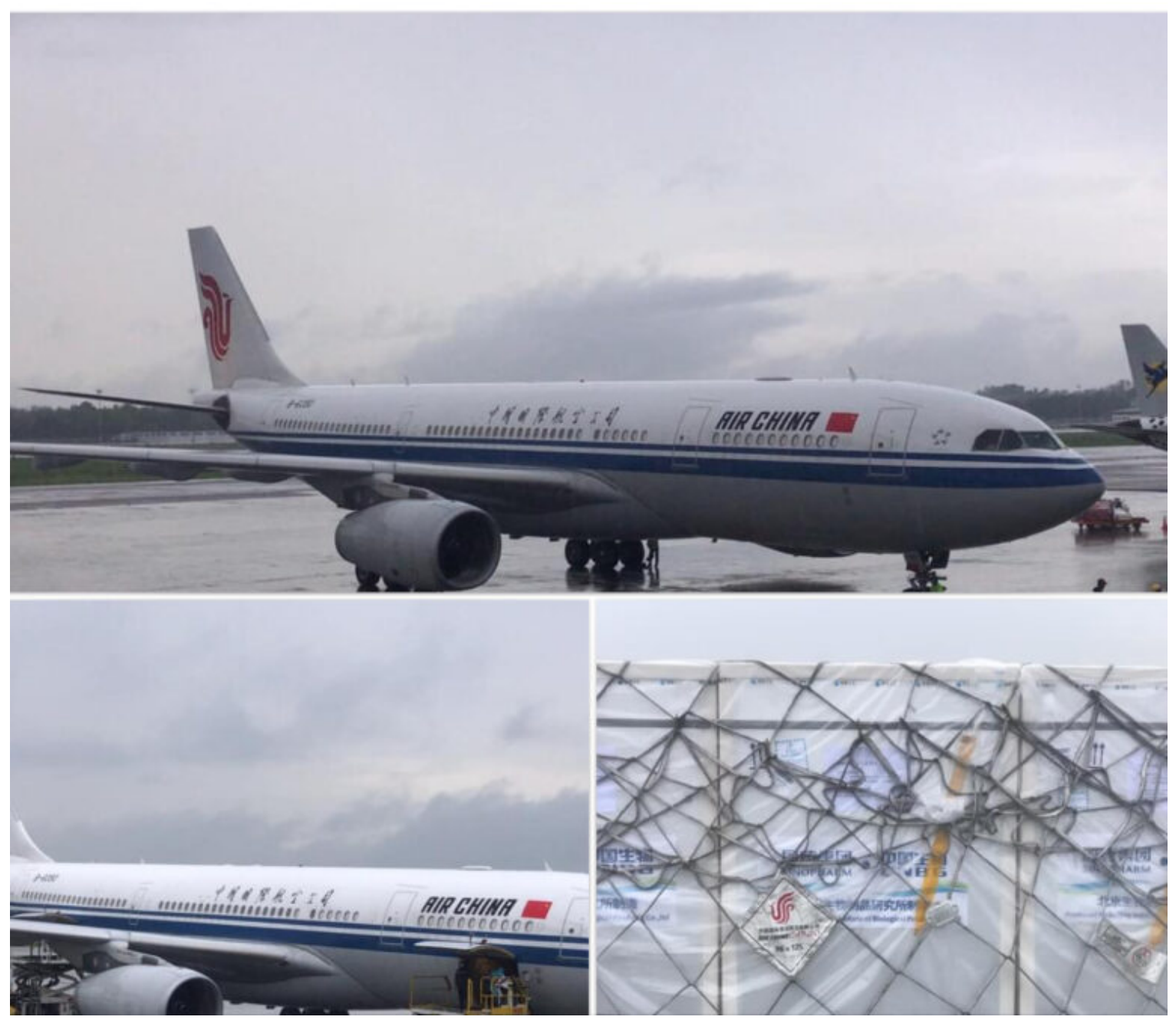


'Since the third wave of the COVID-19 pandemic occurred in Myanmar, China actively helped Myanmar to contact Chinese vaccine producers and secure vaccines at the cheapest prices and as quickly as possible. So far, there have been 20.6 million COVID-19 vaccine doses supported by China to Myanmar, 3.9 million of the doses were donated by China to Myanmar and Myanmar bought 16.7 million doses.' [Translation by the author]

The post, among many by the Embassy since June 2021 when the third and deadliest-so-far wave of COVID-19 engulfed Myanmar, illustrates China's 'vaccine diplomacy' assisting more than 100 countries. This exercise of soft power could be described as building 'health silk roads', an idea and practice that predated COVID-19, in Southeast Asia, Africa, the Middle East and North Africa.

I argue that China's building a China-Myanmar Health Silk Road (CMHSR)-since the outbreak of COVID-19 in Myanmar in March 2020 and working with both the former government of the National League for Democracy and the current military junta, the State Administration Council-relates to China's longer-term geoeconomic and geopolitical interests. The CMHSR is both an offshoot of China's diplomacy regime that promotes its global Belt and Road Initiative (BRI) and its Myanmar portion known as the China-Myanmar Economic Corridor.

\section{'Mask diplomacy', 'vaccine diplomacy', 'health diplomacy', 'soft power' and 'health silk road'}

Academics and journalists use five terms-mask diplomacy, vaccine diplomacy, health diplomacy, soft power, and Health Silk Road-to define the Chinese practice of providing assistance to pandemic-stricken countries. The first two terms are situational and will likely stop being used when or if COVID-19 is no longer a global threat. 
Health diplomacy, soft power, and Health Silk Road are all power-laden and apt descriptions for China's long-term exercise of diplomacy in relation to health issues. I prefer 'Health Silk Road' because it evinces 'Chineseness' and concepts of trade. Chinese leaders and policymakers including President Xi Jinping often use the term. I argue the 'road' metaphor describes well the contact-building between China and other countries, and how China makes inroads into other states and societies.

\section{The origins of COVID-19 and China's response}

Whatever China does, or does not do, is significant and controversial, especially after COVID-19 originated in the Chinese city of Wuhan spread globally from early 2020.

Notoriously, the then-US-president Donald Trump repeatedly called COVID-19 the 'China virus'. That China tried to hide the outbreak in Wuhan or was slow in reporting it flamed a narrative of blame, especially from the US. The way in which the Chinese Communist Party (CCP) under President Xi contained the pandemic within China with extensive restrictions on movement also came into focus. Subsequently, China's help for other countries is also a matter of international attention.

Blame of China has abated, at least for now, notwithstanding continued calls for a scientific analysis of the origin(s) of COVID-19 so that another will not recur undetected. The Trumpian phrases 'China virus' or 'Wuhan virus' are not frequently used currently; instead terms such as vaccine diplomacy and health silk road are more common.

China employs two main strategies to absolve itself of direct or indirect responsibility for the trail of biomedical, economic, political and social devastation left by COVID-19. 
First, China aggressively rejects any further calls for international investigations into the origins of COVID-19. China shows remarkable sensitivity to the 'Lab Leak' theory that postulates that the novel coronavirus was created in the Wuhan Institute of Virology and accidentally, or deliberately, leaked outside it.

Second, China has targeted diplomacy, 'health silk roads', in the developing world in Asia, Africa and the Middle East which have been particularly badly affected by COVID-19 via the donation of vaccines, masks, gloves, protective clothing, and emergency medical teams. Many, if not most, developing countries will not have finished vaccinating their peoples until mid-2022 or beyond and rely on China for help.

In July 2021, a joint letter from 55 nations to the WHO opposed the politisation of COVID-19 and supported the inconclusive results of the World Health Organisation study in China in January and February of that year. Subsequently, Chinese government officials and government-owned or -linked media have celebrated this and others that followed as support of China.

But China may not escape further scientific scrutiny on the origins of COVID-19; and may still find it useful to enlist as much support from as many nations as possible. Building health silk roads is one among policy choices.

\section{China began the CMHSR at the outbreak of COVID-19}

It should be noted that China does not itself articulate a 'health silk road' narrative in Myanmar, perhaps because the broader Myanmar society is wary of Chinese economic and political interests. As a result, China commonly uses the familial Myanmar term pauk-phaw (siblings or relatives), which has the implied Confucian meaning of 'love your family first' and connotes that Myanmar and China are on a par with each other as 'siblings'. Pauk-Phaw is used frequently on COVID-19 donor 
banners, posters and signboards, by Chinese officials and leaders including President $\mathrm{Xi}$, and on the Facebook page of the Chinese Embassy in Myanmar.

The CMHRS is part of the China-Myanmar Economic Corridor that was effectively suspended after the coup on 1 February 2021, when the State Administration Council overthrew the National League for Democracy. When, or if, it is completed, the corridor will connect China's landlocked Yunnan Province to the Kyaukphyu Special Economic Zone in Myanmar's Rakhine State in the west, with access to the Indian Ocean. This would enable China to bypass the maritime chokepoint of the Strait of Malacca, and have access to Yangon and Mandalay, the two biggest cities and most important economic powerhouses of Myanmar. Along the CMEC the Myanmar-China Gas Pipeline and the Myanmar-China Crude Oil Pipeline have been operational since 2013 and 2017 respectively.

China began the CMHSR 18 months ago and has worked with both the former democratically elected National League for Democracy (2016-2020) and the State Administration Council.

China claims to be building the CMHSR for humane reasons and the need is great (but, more importantly, the CMHSR is an offshoot of the BRI/China Myanmar Economic Corridor). The National League for Democracy sought to diversify COVID-19 assistance including vaccines, but the internationally friendless State Administration Council finds it difficult to do so.

China's hitherto multi-layered COVID-19 diplomacy in Myanmar has been State Administration Council-centric since the coup. China has targeted non-governmental actors in Myanmar such as writers, politically active monks, and civil society organisations. Many were relatively easier to approach during the rule of the National League for Democracy, but since the coup many, except ethnic armed groups, have become unapproachable at best because they have been arrested or gone in hiding. 


\section{CMHSR during the rule of the National League for Democracy}

The first two cases of COVID-19 in Myanmar were announced on 23 March 2020, two months after President Xi's tour to Myanmar which was the first of a Chinese head of state in 19 years.

Initially, Chinese nationals, migrant workers and tourists in Myanmar were believed to be carriers of the coronavirus. On 11 February 2020, notably more than a month before COVID-19 was first detected in Myanmar, the Chinese Consulate in Mandalay held a briefing at which they emphasised they were doing everything they could to contain the pandemic.

China donated COVID-19 tests to Myanmar, laying the foundation for the CMHSR as early as 17 March 2020, which was followed by supplies of protective clothing and face masks days later. On 8 April 2020, Yunnan Province, the paradiplomatic proxy of the Chinese Central Government, dispatched a 12-person expert team with more COVID testing kits and personal protective equipment. During field visits to Yangon and Mandalay they shared resources and technical knowledge and learned firsthand what Myanmar was facing and lacking. The then government of the National League for Democracy mobilised public funds and private donations too, but they were insufficient.

The People's Liberal Army, as well as civilian Chinese officials, has helped with the CMHSR. The army helped build a COVID testing laboratory at the No. 1 Defence Services General Hospital in Yangon under the Myanmar military in April 2020, and donated medical equipment to the hospital a month later. A week later, the Yunnanese Buddhist Temple in Mandalay with close links with the Chinese Consulate there also donated supplies to the Myanmar military's central command based in the same city. The temple and the Yangon-based Myanmar Chinese Chamber of Commerce are among key ongoing focal points of China's multi-layered, 
multi-actor construction of CMHSR.

The highest levels of Chinese leadership have also been involved: President Xi had a telephone conversation with Win Myint, Myanmar's then President, on 20 May 2020, and more Chinese technical and material aid was on its way days later.

The first wave of COVID -19 infection in Myanmar abated in mid-July, with officially only 374 cases and six fatalities, though the figures were perhaps low due to limited testing. Chinese aid then was mostly state-centric. But in April of that year Chinese state-owned and semi-state-owned entities with business interests in Myanmar-such as the China Communications Construction Co., Ltd., the Industrial and Commercial Bank of China, the Yangon-Shenzhen Industrial Park Group Company Limited and Wanbao Company-donated supplies. It led to concern that the assistance would have strings attached, but the need was great.

The second and deadlier outbreak of COVID-19 in Myanmar began in August 2020 and continued until February this year. When it began, Chinese government officials (mostly from Yunnan but from Hubei, etc.), semi-governmental or state-owned enterprises and private enterprises continued building and maintaining the CMHSR, often in cooperation with overseas-Chinese Myanmar citizens and Chinese business associations in Myanmar.

No complete record of pandemic aid to Myanmar from different Chinese-related actors exists up until the time of the military coup in February this year. But during my fieldwork in Mandalay and Yangon in December 2020 and January 2021, as well as online ethnography before and during this two-month period, I saw Chinese supplies at offices of civil society organisations and homes of well-known people, or images of such donations posted on Facebook. Facebook pages associated with or backed by China, including that of the Chinese Embassy in Myanmar, featured donations by Chinese actors from China and within Myanmar, both governmental and non-governmental.

Two members of parliament in the Mandalay Region told me that culturally it has 


\section{MELBOURNE ASIA REVIEW}

been very difficult for Myanmar people and associations to refuse the donations, and three civil society organisations told me they had received donations from China without requesting them.

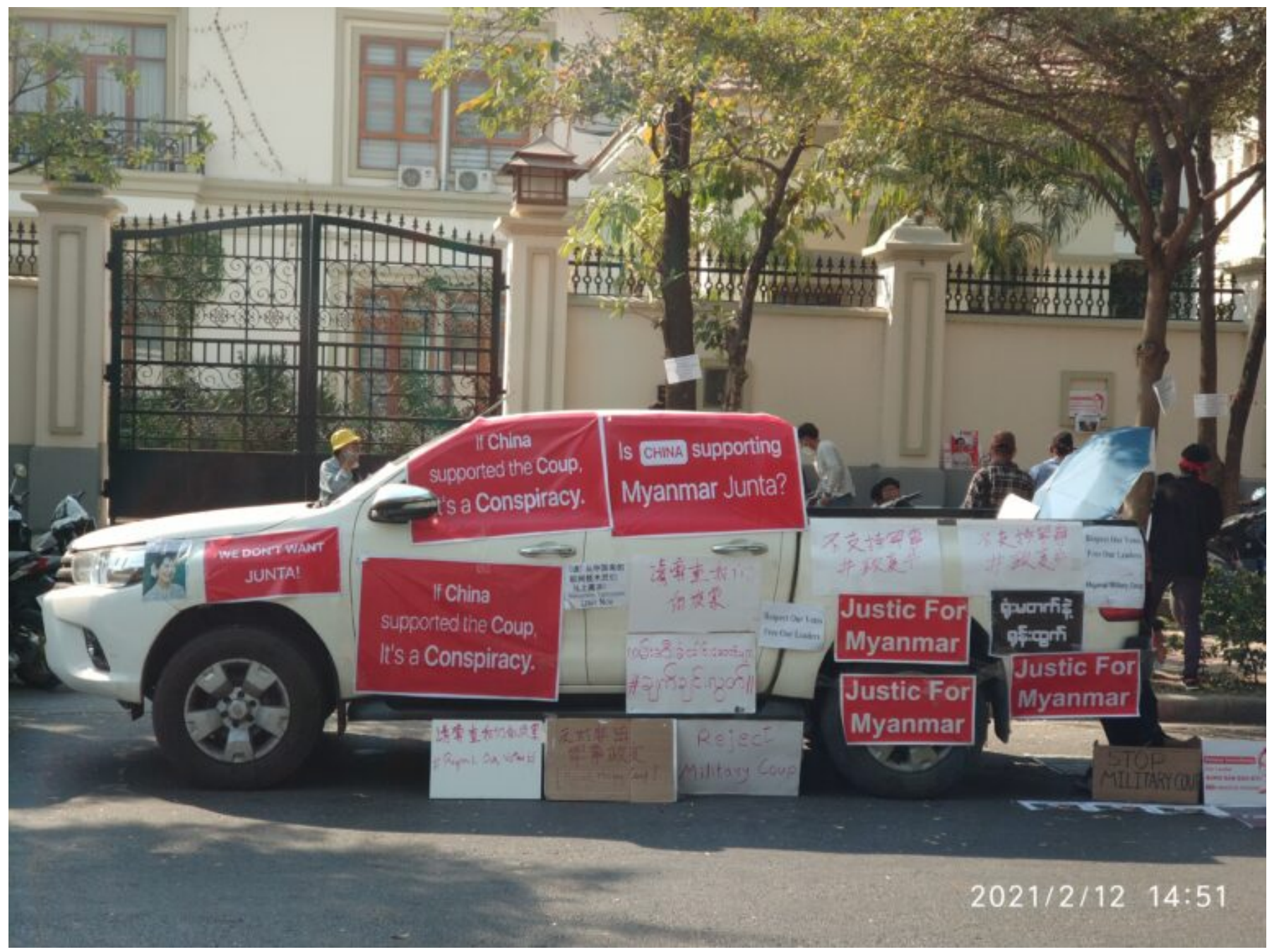

A car with anti-Chinese sentiments outside the Chinese consulate in Mandalay, February 2021. Credit: Author.

\section{CMHSR after the coup}

Despite the deadly suppression of dissent by security forces from March 2021, the State Administration Council has found it difficult to rule Myanmar. Several areas on 
or near Myanmar's borders with China, Thailand and Bangladesh remain under the control of ethnic armed groups, and urban areas are also actively opposing the junta. Myanmar is therefore a failing state. A group of representatives elected in the November 2020 elections, internationally accepted as free and fair, formed the National Unity Government in April 2021. It is composed of ousted parliamentarians, activists, protest leaders, civil society leaders, and representatives of minorities. This parallel government challenges the State Administration Council's legitimacy on the international diplomatic stage and militarily by founding a People's Defence Force in May. The government also declared a 'defensive war' on 7 September, resulting in more armed conflict between State Administration Council forces and their opponents.

In the immediate aftermath of the coup, China had to suspend construction work on the CMHRS, watching with concern the growing tide of anti-China sentiment and protests. Threats against Chinese investments included the oil and gas pipelines for a variety of reasons: China's failure to reject the coup and the junta; protection of the junta at the United Nations; its brokering of a deal between the junta and the Association of Southeast Asian Nations without consulting with the National Unity Government; and speaking with the State Administration Council's chairman Min Aung Hlaing in June this year and referring to him as Myanmar's leader. Despite this, China has made a point of denying complicity with and support of the Myanmar military before and after the coup.

On 14 March 2021, Chinese authorities claimed 32 wholly or partially Chineseowned factories in Yangon were attacked and burned. The Chinese Embassy in Myanmar and the CCP controlled Global Times immediately issued ultimatums, after which the junta declared martial law in parts of Yangon and severely repressed locals. The Facebook page of the Chinese Embassy was inundated with up to tens of thousands of angry comments by frustrated individuals in Myanmar. However, substantial violence towards Chinese investments was not seen again until early October, despite a substantial increase in armed conflict between the State Administration Council and their opponents. 
The third wave of COVID-19 spread in Myanmar from June 2021, by which time China had effectively recognised the State Administration Council as the nation's new governing body. This wave has been the deadliest, mainly because of the systemic breakdown of Myanmar's public health sector due to tens of thousands of medical professionals' joining the Civil Disobedience Movement and refusing to work at public hospitals under the State Administration Council. Figures provided by the junta indicate there were 3,921 fatalities from 1 June to 25 July, a number higher than the total in the first two waves. These statistics are far lower than that expected by citizens and private underground media who reported hundreds of thousands of cases of COVID-19.

In the first two waves of the pandemic, Myanmar under the National League for Democracy sought to secure vaccines from India rather than China. In January 2021, Myanmar ordered 30 million doses of AstraZeneca/COVIDSHEILD made by the Serum Institute of India. Days before the coup, India donated 1.5 million doses of COVISHIELD to Myanmar.

When the third wave began, State Administration Council chairman Min Aung Hlaing initially showed desire to diversify supplies, including acquiring vaccines from Russia. Indian, Chinese and Russian armies donated several hundreds of thousands of vaccines to the Myanmar army.

But Myanmar ran into trouble with the COVAX global vaccine-sharing program after the State Administration Council failed to share details of its vaccination program, and the rest of the order of 30-million doses from India has not arrived for undisclosed reasons. The vaccine-rollout has therefore been hampered by insufficient supply, as well as unwillingness by the Myanmar public to receive vaccines through the State Administration Council.

China spotted the gap in Myanmar and acted. For the State Administration Council, Chinese offers of vaccines have been irresistible and Myanmar is relying on China alone for them, notwithstanding some opposition for both political reasons and 
doubts relating to their efficacy. In its usual multi-layered manner, China donates and sells vaccines to not just the State Administration Council, but ethnic armed organisations and overseas Chinese associations in Myanmar such as the Myanmar Chinese Chamber of Commerce and the Yunnanese Buddhist Temple.

At the time of writing, the number of COVID-19 infections is decreasing, but Myanmar has only fully vaccinated approximately 10 percent of its population. The State Administration Council currently has no option but to continue to rely on China. Myanmar's Ministry of Health under the State Administration Council issued a statement on 1 September, stating that 'Searching the origins of the coronavirus should be conducted scientifically for treatment, and it should not blame or give political pressure on other countries.' The SAC-appointed health minister Thet Khaing Win repeated his ministry's statement in a meeting with Chinese officials on 3 September. On 5 October, the Ministry of Health released a statement pledging cooperation with the vaccine-sharing program. When or whether Myanmar will receive vaccines from COVAX is not known yet. But the statement shows the State Administration Council's awareness of its dependency on China for vaccines.

\section{A difficult road ahead}

I expect further complications relating to the CMHSR and it may never be completed. Myanmar's vaccination program will be slow and a fourth wave is possible. The State Administration Council will continue to rely on China, and Myanmar people will have no option but to receive Chinese vaccines, as many have done in recent months.

China will leverage this to pressure the State Administration Council to continue to protect Chinese interests. But China is also reaching out to the National League of Democracy. After China reportedly brokered a deal with the US to effectively deny recognition of Myanmar's UN ambassador appointed by the State Administration Council, Myanmar public opinion towards China improved. In August, China also 
protected the National League of Democracy from being disbanded by the State Administration Council, and in September the CCP invited the NLD to attend a virtual meeting. On 1 October, the Prime Minister of the National Unity Government, Mahn Winn Khaing Than, sent a congratulatory letter on the $72^{\text {nd }}$ anniversary of the founding of China which states 'The NUG stands ready to partner with China.'

China will vacillate between the State Administration Council and the National Unity Government in the near future. It is indubitably conscious of Myanmar public opinion and is in a wait-and-see mode, but it will most likely work with whomever is in power and can promise protection of its national interests and the continuation of the China-Myanmar Economic Corridor. The continued construction of the CMHSR may or may not improve the image of China within Myanmar, subject to changes in Myanmar politics.

Main image: Protesters in front of the Chinese consulate in Mandalay, February 2021. Credit: Author. 